\title{
BDNF Polymorphism: A Review of Its Diagnostic and Clinical Relevance in Neurodegenerative Disorders
}

\author{
Ting Shen ${ }^{1, *}$, Yuyi You ${ }^{2}$, Chitra Joseph ${ }^{1}$, Mehdi Mirzaei ${ }^{3}$, Alexander Klistorner ${ }^{1,2}$, Stuart L. \\ Graham $^{1,2}$, Vivek Gupta ${ }^{1}$
}

${ }^{1}$ Faculty of Medicine and Health Sciences, Macquarie University, Australia

${ }^{2}$ Save Sight Institute, Sydney University, Sydney, Australia

${ }^{3}$ Faculty of Science and Engineering, Macquarie University, Australia

[Received May 25, 2017; Revised June 30, 2017; Accepted July 17, 2017]

\begin{abstract}
Brain-derived neurotrophic factor (BDNF) has a unique role in the neuronal development, differentiation, and survival in the developing and adult nervous system. A common single-nucleotide polymorphism in the pro-region of the human BDNF gene, resulting in a valine to methionine substitution (Val66Met), has been associated with the susceptibility, incidence, and clinical features of several neurodegenerative disorders. Much research has been dedicated to evaluating the effects of polymorphism in the past decade, and functional effects of this genetic variation. A better understanding of how this naturally occurring polymorphism associates with or influences physiology, anatomy, and cognition in both healthy and diseased adults in neurodegenerative conditions will help understand neurochemical mechanisms and definable clinical outcomes in humans. Here we review the role and relevance of the BDNF Val66Met polymorphism in neurodegenerative diseases, with particular emphasis on glaucoma, multiple sclerosis (MS), Alzheimer's disease (AD) and Parkinson's disease (PD). Several controversies and unresolved issues, including small effect sizes, possible ethnicity, gender, and age effects of the BDNF Val66Met are also discussed with respect to future research.
\end{abstract}

Key words: BDNF, polymorphism, neurodegenerative diseases, glaucoma, multiple sclerosis, Alzheimer's disease

Neurotrophins are a family of growth factors crucial for the regulation of neuronal maintenance, differentiation, and survival. Among the neurotrophins, the dysregulation of brain-derived neurotrophic factor (BDNF) has been implicated in enhanced vulnerability to neurodegenerative diseases. The deficiency of BDNF, though not necessarily the initial trigger for the disease process, may result in accelerated cell damage and other associated symptoms. A naturally occurring polymorphism in the human BDNF gene leading to an amino-acid residue substitution from valine (Val) to methionine (Met) at position 66 within the pro-region of
BDNF, results in a functional single-nucleotide polymorphism (SNP) that possibly results in altered BDNF activity-dependent secretion [1]. The role and association of the BDNF polymorphism with various neuropsychiatric disorders has been extensively reviewed [2]. Several studies have emerged implicating the association or otherwise of this polymorphism with neurodegenerative disorders of the central nervous system (CNS), such as Alzheimer's disease (AD), multiple sclerosis (MS), and Parkinson's disease (PD), and also glaucoma which is characterised by optic nerve degeneration. This review comprehensively assesses the

*Correspondence should be addressed to: Ting Shen, Faculty of Medicine and Health Sciences, Macquarie University, Sydney, NSW2109, Australia. Email: ting.shen1@students.mq.edu.au

Copyright: ( 2017 Shen T et al. This is an open-access article distributed under the terms of the Creative Commons Attribution License, which permits unrestricted use, distribution, and reproduction in any medium, provided the original author and source are credited. 
literature on BDNF polymorphism in these pathological conditions with a view to better understand its potential involvement or association with these disorders.

\section{Brain-derived neurotrophic factor (BDNF) and neurodegeneration}

The neurotrophin family consists of four major types of structurally related proteins with similar function, namely the nerve growth factor (NGF), brain-derived neurotrophic factor (BDNF), neurotrophin-3 (NT-3) and neurotrophin-4 (NT-4). The neurotrophins have similar molecular weights $(13.2-15.9 \mathrm{kDa})$, isoelectric points (within the range of 9-10), and share approximately $50 \%$ of the identity in primary structure [3, 4]. Among these neurotrophins, BDNF has emerged as a major regulator for several types of neurons, including sensory neurons, retinal ganglion cells, spinal motor neurons, certain cholinergic neurons, and some dopaminergic neurons [5]. It has been reported that some BDNF precursor (proBDNF) is released extracellularly and mediates tropomyosin receptor kinase $\mathrm{B}$ (TrkB) receptor phosphorylation [6]. The synthesis of BDNF is influenced by neuronal activity in the brain and plays a unique role in synaptic transmission and plasticity. BDNF is widely expressed in the CNS, and its expression is decreased in several neurodegenerative diseases as demonstrated by post-mortem studies, including in AD [7-9], PD [10], and Huntington's disease (HD) [11]. It has also been demonstrated that BDNF concentration is reduced in individuals with major depression and increases after antidepressant drug treatment [12].

The trophic effects of BDNF are mainly mediated through its high-affinity receptor TrkB, which upon activation undergoes phosphorylation and dimerization of its specific intracellular tyrosine residues. In the developing hippocampus, BDNF and TrkB signalling plays a pivotal role in mechanisms associated with neuronal plasticity such as long-term potentiation (LTP). LTP represents a persistent strengthening of synapses in between nerve cells that plays a key role in learning and memory formation [13]. While the application of exogenous BDNF was shown to facilitate LTP, the decrease of BDNF levels by gene knock-out in mice attenuated LTP in the hippocampus $[14,15]$. BDNF also binds to its low-affinity receptor $\mathrm{p} 75$ which is a member of the tumour necrosis factor receptor (TNFR) superfamily. The $\mathrm{p} 75$ activation at the cytoplasmic region results in subsequent activation of NFkB which induces programmed cell death (apoptosis) [16]. The neurotrophins together with their receptors play pivotal roles in the regulation of various cell signalling pathways linked to growth, differentiation, survival, and apoptosis [17].
The exogenous administration of BDNF could be a valuable therapeutic approach for related diseases. It has been reported previously that intraventricular administration of recombinant human BDNF (rhBDNF) partially protects the basal forebrain cholinergic neurons from axotomy-induced degenerative changes in a rat model [18]. Similarly, intravitreal injection with BDNF can enhance retinal ganglion cell (RGC) survival in the cat optic nerve crush model [19]. However, while an insufficient dose might not produce the desirable effects, an indiscriminate overload of BDNF may also lead to inflammation, reduced cell survival or even potentially exacerbated seizure development [20]. Thus, future studies are warranted to explore the optimal dosage and administration methods and novel approaches to minimise non-specific side effects for potential clinical application.

\section{BDNF polymorphisms}

The BDNF gene is localized on chromosome 11 band $\mathrm{p} 13$ [4] and comprises 11 exons and 9 functional promoters [21]. It can produce at least 34 mRNA transcripts responding to a variety of stimuli [22].

The typical and most widely used method for genotyping the BDNF polymorphism is by polymerase chain reaction - restriction fragment length polymorphism (PCR-RFLP). Enzymatic digestion with the specific restriction enzyme (RE) is performed on PCR products and the genotype of the subject can be identified subsequently from the gel electrophoresis results [23, 24]. PCR genotyping method of amplified refractory mutation system was reported to be cost-effective, efficient, and as reliable as PCR-RFLP for detecting BDNF polymorphisms [25]. Direct sequencing is also able to detect the genetic alteration and is commonly used to confirm the doubtful results obtained after the RE digestion $[23,26]$. In addition to small scale projects aiming to identify a single polymorphism, several genotyping approaches such as TaqMan assay, fluorescence polarization, pyrosequencing, SNP gene chip based assay, and mass spectrometry based assay and so on have also enabled medium to high throughput (hundreds to tens of thousands of genotypes a day) as well as multiple SNP detection and was described extensively in previous reviews [27-29].

\section{Val66Met}

The understanding of BDNF function in humans has greatly benefited from the identification of a SNP in the BDNF gene that causes a valine (Val) to methionine (Met) substitution at codon 66 (Val66Met, c.196G $>$ A, dbSNP: rs6265). In this Met variant form of BDNF carriers, that is, BDNF $\mathrm{Val} / \mathrm{Met}$ heterozygotes and Met/Met 
homozygotes, the pro-domain structure of the gene is altered. Though this alteration would not necessarily change the intrinsic biological activity of the mature BNDF protein, the polymorphism can lead to improper protein folding and a reduced binding of the mature BDNF to its receptor TrkB, causing impairments in hippocampal function [1]. The polymorphism can potentially alter BDNF protein-protein interactions, binding affinities, localisation, or conformational stability of the protein. Whether the polymorphism has any significant impact on the proteome profile or posttranslational modifications of various proteins in the neuronal tissues or body fluids is currently unknown. It has been reported that BDNF Val66Met may have roles in susceptibility for migraine, especially for migraine with aura (MA) subtype [30]. The Val66Met polymorphism is not known to occur naturally in other vertebrate species except the human so far [31].

Table 1. Allele and genotype distributions for the Val66Met polymorphism of Brain-derived neurotrophic factor (BDNF) in healthy subjects in different ethnicity.

\begin{tabular}{|c|c|c|c|c|c|c|c|c|}
\hline \multirow[t]{2}{*}{ Ethnicity } & \multirow[t]{2}{*}{ Cohort } & \multirow{2}{*}{$\begin{array}{l}\text { Total } \\
\mathbf{N}\end{array}$} & \multirow[t]{2}{*}{ Reference } & \multicolumn{2}{|c|}{ Allele frequency } & \multicolumn{3}{|c|}{ Genotype } \\
\hline & & & & $\begin{array}{c}\text { A (Met) } \\
\%\end{array}$ & $\begin{array}{c}\mathrm{G}(\mathrm{Val}) \\
\%\end{array}$ & $\begin{array}{c}\text { A/A } \\
\text { (Met/Met) } \\
\%\end{array}$ & $\begin{array}{c}\text { G/A } \\
\text { (Val/Met) } \\
\%\end{array}$ & $\begin{array}{c}\mathrm{G} / \mathrm{G} \\
(\mathrm{Val} / \mathrm{Val}) \\
\%\end{array}$ \\
\hline \multirow[t]{6}{*}{ Asian } & Korea & 244 & Pivac et al. 2009 & 46.3 & 53.7 & 23.4 & 45.9 & 30.7 \\
\hline & Japan & 657 & Fukumoto et al. 2009 & 39.0 & 61.0 & 15.0 & 47.0 & 38.0 \\
\hline & Japan & 275 & Nishimura et al. 2009 & 42.5 & 57.5 & 17.1 & 50.9 & 32.0 \\
\hline & China & 239 & Bian et al. 2005 & 45.4 & 54.6 & 21.3 & 48.1 & 30.5 \\
\hline & Japan & 471 & Matsushita et al. 2005 & 44.5 & 55.5 & 20.8 & 47.4 & 31.9 \\
\hline & Japan & 151 & Itoh et al. 2003 & 41.1 & 58.9 & 15.9 & 50.3 & 33.8 \\
\hline \multirow[t]{12}{*}{ Caucasian } & Romania & 1124 & Vulturar et al. 2016 & 19.3 & 80.7 & 4.0 & 30.5 & 65.5 \\
\hline & Poland & 193 & Nowak et al. 2014 & 15.0 & 85.0 & 1.0 & 30.0 & 69.0 \\
\hline & Croatia & 556 & Pivac et al. 2009 & 19.5 & 80.5 & 3.4 & 32.4 & 64.2 \\
\hline & Italy & 233 & Guerini et al. 2009 & 20.6 & 79.4 & 4.3 & 32.6 & 63.1 \\
\hline & Italy & 37 & Liguori et al. 2009 & 17.6 & 82.4 & 2.7 & 29.7 & 67.6 \\
\hline & USA & 250 & Zhang et al.2006 & 18.8 & 81.2 & 4.0 & 29.6 & 66.4 \\
\hline & Finland & 920 & Vepsalainen et al. 2005 & 13.0 & 87.0 & 2.0 & 24.0 & 75.0 \\
\hline & USA & 194 & Bodner et al. 2005 & 19.0 & 81.0 & 3.0 & 32.2 & 64.7 \\
\hline & USA & 392 & Parsian et al. 2004 & 28.0 & 72.0 & 2.0 & 53.0 & 45.0 \\
\hline & Spain & 218 & Combarros et al. 2004 & 19.0 & 81.0 & 3.7 & 30.7 & 65.6 \\
\hline & USA & 133 & Egan et al. 2003 & 18.0 & 82.0 & 4.5 & 27.1 & 68.4 \\
\hline & Italy & 111 & Ventriglia et al. 2001 & 29.7 & 70.3 & 8.1 & 43.2 & 48.7 \\
\hline
\end{tabular}

Several studies have described the distribution of Met allele carriers in healthy participants across the world. The Val66Met polymorphism frequency varies depending on both region and ethnicity. A 0 to $72 \%$ Met allele frequency was presented in a population genetic study of BDNF [32]. Specifically, the Met carriers make up approximately $30 \%$ to $50 \%$ of Caucasian populations in cohorts from the U.S. (31.6\%), Croatia (35.8\%) and Italy (51.30\%) [33-35]. Whereas among Asian populations, almost $70 \%$ of people in China (69.5\%), Japan (66.20\%) and Korea $(69.30 \%)$ carry the Met variant form of BDNF gene [24, 33, 36] (See Table. 1). Significant ethnic differences for the Val66Met were also reported in these studies, providing a possible explanation for the various conflicting associations demonstrated between the polymorphism and neuronal disorders.

\section{Other BDNF gene variants}

Besides Val66Met, other BDNF gene polymorphisms are also reported to exhibit possible positive or negative association with various deficits indifferent neuronal 
disorders. The C270T (rs56164415) polymorphism located in the non-coding region of BDNF was found to be associated with increased risk of late-onset Alzheimer's disease (LOAD) and also linked with susceptibility to and the onset of MS [37, 38]. The rs2030324 polymorphism was specifically shown to affect visual cognitive processing in MS patients [39]. However, other studies suggested no significant associations between these polymorphisms and risks for neurological diseases [34, 40-44].

\section{The effects of Val66Met polymorphism on neurodegenerative disorders}

Since neurotrophins are essential for neuronal function, development, survival and regeneration, gene variations encoding these proteins can confer susceptibility to neurodegenerative disorders [45].

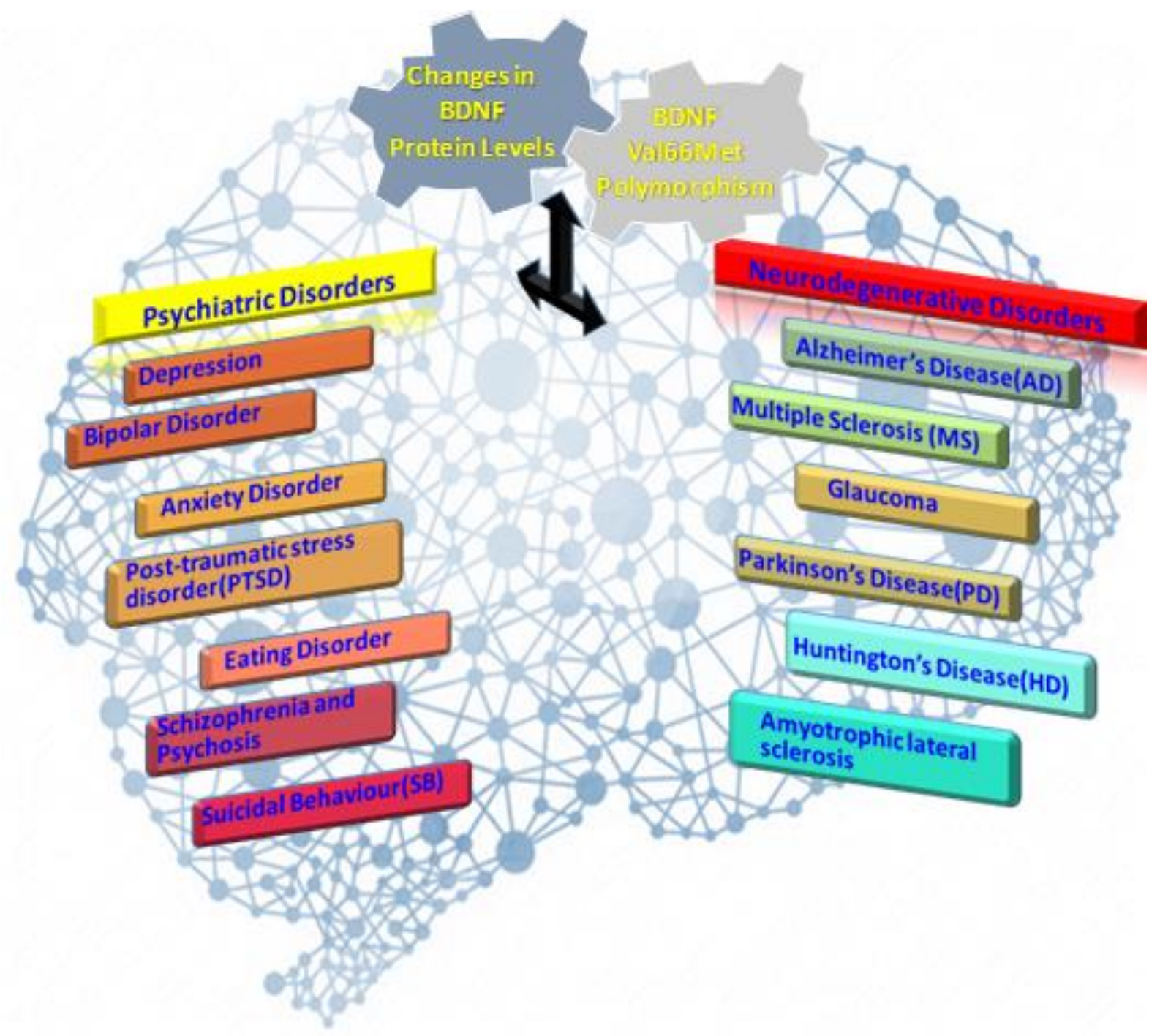

Figure 1. Changes in Brain-derived neurotrophic factor (BDNF) protein levels and BDNF Val66Met polymorphism as modifiers of neurodegenerative disorders and psychiatric disorders. 
The Met allele was hypothesized to impair intracellular trafficking and synaptic localization of mature BDNF and significantly weaken the activitydependent secretion of BDNF (up to $30 \%$ ) while keeping the constitutive secretion of BDNF unaffected [1]. A similar reduction of activity-dependent BDNF secretion was also observed in neurons derived from BDNF Val66Met knock-in mice [46]. However, inconsistent results of higher [47, 48], lower [49] as well as similar [50, 51] levels of BDNF serum concentration in Met carriers have been reported in genetic association studies. The conflicting results could be due to psychopathology, ethnicity and/or gender difference [52].

Magnetic resonance imaging (MRI) analysis indicated that the BDNF polymorphism has an impact on the anatomy of the hippocampus and prefrontal cortex in healthy human subjects. The Met carriers exhibited significant bilateral decrease of hippocampal grey matter volumes compared to Val homozygotes, suggesting a modifying effect of the functional variation in brain morphology related to learning and memory [53]. Interestingly, a longitudinal study illustrated that although the BDNF Val homozygotes outperformed the Met carriers at the first testing session for cognitive function, they showed a substantial decrease in performance after 10 -years' time at the second session [54]. This result is partially consistent with an earlier study demonstrating a better performance in Met homozygotes in older age [55], suggesting that the BDNF impact on cognitive function may alter during the human lifespan and that the Met allele may provide neuronal protection during later stages of life. A recent study also reported a positive effect of Met homozygosity on regional grey matter volume (rGMV) in healthy Japanese children and adolescents, suggesting a possible role the Val66Met have on human development [56]. These emerging results continue to substantiate the role of BDNF Val66Met in the susceptibility and progression of neurodegenerative diseases.

\section{Glaucoma}

Glaucoma is a group of complex neurodegenerative diseases characterised by progressive degeneration of retinal ganglion cells (RGCs), cupping of the optic nerve head $(\mathrm{ONH})$ [57], and abnormal thinning of retinal nerve fibre layer (RNFL) [58], resulting in irreversible loss of vision and visual sensitivity. It has been estimated that almost 80 million people will suffer from glaucoma by 2020 with approximately $14 \%$ being bilaterally blind, making glaucoma the second leading cause of irreversible blindness worldwide [59].

A strong genetic basis of the disease predisposition is supported by several lines of studies in both primary open angle (POAG) and closed angle glaucoma [60-63]. However, these susceptibility genes that have been identified so far account for just a small proportion of glaucoma cases and have only modest effect size in elucidating the risk for glaucoma. There is an opportunity to explore disease modifiers and cross-talk between already identified gene variants for a better understanding of the disorder.

Accumulating evidence suggests that molecules with neurotrophic actions such as BDNF affect RGC development and maintenance. Inside the retina, BDNF is expressed by cells in the inner nuclear layer (INL) and ganglion cell layer (GCL) [64]; its cellular target TrkB receptor is produced by RGCs and amacrine cells [65] that support the BDNF trophic actions. The axonal transport of BDNF and TrkB receptor are suggested to be obstructed in both acute and chronic experimental glaucoma models, suggesting that deprivation of BDNF to RGCs contributes to the pathogenesis of neuronal loss in glaucoma [66].

Several studies have shown that BDNF acts as a potent neuroprotectant for RGCs after optic nerve (ON) injury $[19,67]$ and after increased IOP which mimics the primary open-angle glaucoma (POAG) $[68,69]$. In most studies, BDNF was administered to the intraocular tissues by intravitreal injection. However, a recent study utilizing topical eye application of BDNF eye-drops on mice showed a similar protective result in animals with experimental glaucoma [70]. In addition, overexpressing the BDNF gene by introducing the modified adenoassociated viral (AAV) vector into the rat retina also demonstrated a similar neuroprotective effect for laserinduced experimental glaucoma, providing support for the concept of potential gene therapy applications in human glaucoma [71].

As a functional genetic alteration for BDNF, the Val66Met polymorphism was reported to be significantly associated with progression of POAG determined by the nerve fibre layer analyser (GDx) but not with the risk of POAG in a Polish cohort [72]. This result suggested that Val66Met may have a role in glaucomatous RGC loss.

\section{Multiple sclerosis (MS)}

Multiple sclerosis (MS) is a chronic autoimmune, inflammatory neurological disorder of the CNS. MS progression leads to demyelination, axonal degeneration and subsequent neurological impairment and disability [73]. More than 2.3 million people worldwide were affected with MS by 2013 , and up to $60 \%$ of patients will need walking assistance within 20 years after the onset of disease [74]. The disease typically presents in young adults with an average age of onset of 29 years and affects twice as many women as men [75]. Several ancillary tests 
can be used to support clinical diagnoses, such as brain MRI, sensory evoked potential testing, cerebrospinal fluid analysis and serologic testing [73].

Since genetic factors were demonstrated to affect the susceptibility to MS, series of genome-wide association studies have been performed and multiple SNPs that are associated with MS have been identified, including polymorphisms in genes for interleukin 2 receptor alpha, interleukin 7 receptor, rs703842 and rs10876994 on chromosome 12, and CD40 on chromosome 20 [76, 77]. However, these SNPs individually exert only modest effects on the overall MS risk and were reported to have no association with the MS disease severity measures [78].

A two-year longitudinal study showed higher peripheral BDNF mRNA levels in relapsing-remitting multiple sclerosis (RRMS) patients with Met alleles with respect to Met carriers of healthy controls, suggesting that the BDNF polymorphism may affect the peripheral BDNF production during RRMS [79]. Another study also reported opposite effects on BDNF polymorphism association with parieto-prefrontal network activation and hippocampal disengagement in controls and RRMS subjects by working memory challenges [23].

The attempts to explore the influence of BDNF Val66Met polymorphism on the brain of MS patients have produced conflicting results. In an earlier study, RRMS patients with Met alleles, relative to healthy controls with matching age, gender, and educational levels or MS patients with two Val alleles, exhibited a lower volume of cerebral grey matter (GM). The Met carriers also had a higher risk to develop global grey matter atrophy than the $\mathrm{Val} / \mathrm{Val}$ homozygous RRMS patients [80]. On the contrary, several later studies showed an opposite result where the Met carriers had increased grey matter volume in the brain and had possible protective effect for grey matter preservation in MS [81, 82]. The discrepancies might result from the differences in cohort selection as the former was carried out in RRMS patients without treatment and with low disability while the latter studies had cohorts of treated MS patients. It has also been suggested that differential effects could have been caused by Met allele on subsequent brain volume change, by directly affecting neuronal BDNF secretion, and indirectly influencing the inflammatory activity or possibly affecting secondary secretion of BDNF by immune cells, although the effect of oedema on lower brain atrophy could not be excluded [83]. Further, an fMRI study showed that the Val66Met polymorphism has differential effects on the hippocampal memory system of healthy controls and RRMS patients. Particularly, in RRMS patients, the Met allele carriers showed increased hippocampus posterior cingulate cortex connectivity in comparison with Val homozygotes during retrieval phase of the episodic memory task while the reverse was true for controls [84].

In a Polish cohort, the Val homozygotes were found to have increased MS susceptibility in females and earlier onset of disease in males, suggesting a gender difference in the effect of the polymorphism on MS [38]. The BDNF Val66Met polymorphism showed no significant influence on the severity of depression in MS patients, though the result was in disagreement with the findings based in the general population [85]. Negative results were also reported in MS susceptibility and clinical course in human cohorts from the UK, Norway, and Spain [44, 86, 87]. Future studies with larger sample sizes are needed, particularly with a special focus on gender and ethnic differences.

Many epidemiological studies have reported a higher prevalence and incidence of MS in Caucasian populations than in Asian [88, 89]. However, the prevalence of neuromyelitis optica (NMO), a more severe demyelinating disorder, is higher in Asian population [9092]. Since the BDNF Met allele frequency is substantially higher in Asians compared to Caucasians, one would expect this genetic variation might be associated with a higher prevalence if it was associated with the pathogenesis of MS. Larger studies of different ethnic groups with matching age, sex ratio, MS subtypes, etc. and with high statistical power need to be conducted to test the hypothesis.

\section{Alzheimer disease (AD)}

Alzheimer disease (AD) is an irreversible neurodegenerative disorder associated with specific pathological changes leading to neurodegeneration and progressive symptoms of dementia. AD is clinically characterized by memory impairment, loss of cognitive functions and behavioural impairment, and pathologically by the presence of beta amyloid (A $\beta)$ andhyperphosphorylated Tau protein plaques along with neurofibrillary tangles in the brain [93]. It has been estimated that 26.6 million people worldwide were afflicted with $\mathrm{AD}$ in 2006, and the global prevalence is expected to quadruple to approximately 106 million by the year of 2050 [94]. Despite major efforts in research and drug development, no effective treatments or drugs have been developed to prevent $\mathrm{AD}$ progression [95].

Attempts are in progress to flag and diagnose individuals with high-risk for $\mathrm{AD}$ in an early stage by genetic screening tests, and such risk-assessment profile would enable future personalized treatment plans. Several gene missense mutations predisposing to increased $\mathrm{AD}$ susceptibility have been identified and validated. For instance, genes encoding amyloid precursor protein [96], presenilin 1 [97], and presenilin 2 [98] confer 
susceptibility to familial AD. The genetic alterations in presenilin genes are the most common cause of familial $\mathrm{AD}$ while the mutations in APP account for only very rare cases [99]. The $\varepsilon 4$ allele of the apolipoprotein E (APOE) is a major genetic predisposing factor for both familial and sporadic AD [98]. However, AD is a genetically complex disorder and the overall susceptibility cannot be fully explained by the aforementioned genes. Thus, additional gene alterations and linkages may dictate the development and progression of various subtypes of $\mathrm{AD}$.

Some studies suggest that there is altered function of the BDNF gene in the pathogenesis of AD. A sexually dimorphic effect of the BDNF Val66Met mutation on AD development was observed in a large sampled metaanalysis study $(4,711$ patients and 4,537 controls included). The female Met allele carriers depicted a higher prevalence of $\mathrm{AD}$, but such an association was not found in male carriers [41]. The female BDNF Val carrier patients were also found to have delayed age of onset for the disease as well as a protective effect in regard to $A D$ development in a Chinese cohort [24].

A case-control study in a Japanese population reported a higher Met allele frequency in $\mathrm{AD}$ subjects in comparison with the cognitively normal controls, suggesting that BDNF Met allele may play some role in the development of the disease [42]. In addition, it has been suggested that the BDNF Val66Met polymorphism moderates the memory decline and hippocampal atrophy in prodromal $\mathrm{AD}$ subjects with high baseline levels of $\mathrm{A} \beta$ [100]. Comparing to Val/Val homozygotes, significantly higher rates of hippocampal atrophy and accelerated episodic memory decline were observed in BDNF Met carriers with amnestic mild cognitive impairment (aMCI) and high $A \beta$ density. However, the rate of $A \beta$ accumulation was not moderated by the BDNF polymorphism, suggesting that the polymorphism may accelerate neurodegeneration and memory decline by influencing downstream processes, such as tau aggregation [100]. Similarly, a significant decline of hippocampal volume and memory was observed in healthy BDNF Met carriers with high A $\beta$ levels [101].

A recent study exploring the effects of BDNF Val66Met on autosomal dominant Alzheimer's disease (ADAD) showed greater deleterious effects of $A \beta$ on episodic memory, hippocampal function, and tau in preclinical ADAD mutation carriers with Met alleles [102]. In addition, an early study showed that the number of individuals who were homozygous for Val allele was significantly higher in $\mathrm{AD}$ subjects compared to the controls, suggesting an increased risk of $\mathrm{AD}$ in people with two Val alleles [35].

In contrast, no association between BDNF Val66Met polymorphism and risk of LOAD was observed in Japanese [103], Chinese [104], Spanish [105], Finnish
[42], Italian [106], and American [40] cohorts. The reduced level of BDNF protein in temporal neocortex region of the $\mathrm{AD}$ subject brains did not correlate with BDNF Val66Met [107]. These conflicting results have led to suggestions that BDNF Val66Met polymorphism may only act as a modifier in early-onset cases rather than the LOAD. However, it is to be acknowledged that the studies showing a negative result had medium to small sample size ranging from 163 to $256 \mathrm{AD}$ patients, and the lack of sufficient statistical power could also lead to ambiguous outcomes. Furthermore, recent studies have revealed an association between another BDNF polymorphism C270T (where a $\mathrm{C}$ to $\mathrm{T}$ substitution occurred within the non-coding region of BDNF gene) and LOAD [37, 103, 108] raising the possibility that Val66Met may be in linkage disequilibrium with other variants either within or close to the BDNF gene.

\section{Parkinson's disease (PD)}

Parkinson's disease is a progressive neurodegenerative disease featured by the death of dopaminergic neurons in the substantia nigra and the presence of Lewy bodies [109]. Like other neurodegenerative disorders showing non-mendelian inheritance, the pathogenesis of PD remains unclear, however several studies implicate a complex interplay between genetic and environmental impacts in the causation of PD [110].

A significantly reduced BDNF mRNA expression was reported in PD substantia nigra pars compacta (SNpc) compared to control neurons in an early post-mortem human study, although this reduction could partially be due to the loss of SNpc dopaminergic neurons which specifically express BDNF. Surviving dopaminergic neurons in the SNpc of PD patients express less BDNF than healthy controls, suggesting that the decrease of BDNF might contribute to the loss of nigral dopaminergic neurons and pathogenesis of PD [111]. The serum BDNF levels were also found to be decreased in PD subjects [112].

Emerging evidence increasingly indicates that the BDNF polymorphism possibly modulates the prevalence or clinical course of PD. Association studies of 20 candidate gene SNPs for PD have revealed that the Met/Met genotype frequency is higher in PD patients than healthy controls in a Japanese cohort [113]. A later onset age of 5.3 years has been reported in BDNF Met homozygotes with familial PD compared to the heterozygotes and Val homozygotes in a UK study [114]. Two more studies elucidated that the BDNF Met allele carriage is associated with a higher prevalence of cognitive impairment in PD patients, indicating that the polymorphism may be a risk factor for cognitive dysfunction in PD $[115,116]$. The PD patients with Met 
alleles were reported to develop levodopa induced dyskinesia (LID) earlier during treatment with dopaminergic agents [117] than those with two Val alleles. There is also evidence that the BDNF genotypes independently influence the planning task performance of the tower of London (TOL) test in PD patients, even after adjustment for other possible confounding factors, however, the better performance in Met carriers was reported to be significant only in female but not in the male participants [109]. The BDNF Met carriers with PD were also demonstrated to have significantly smaller decline in set shifting (cognitive flexibility that includes the ability to shift attention between tasks) during a twoyears later follow-up test compared to the Val homozygotes, indicating a possible beneficial effect of the Met allele on mental flexibility [118].

Nevertheless, conflicting results still persist as previous studies from Finland [119], Sweden [120], Taiwan [121, 122], Greece [123, 124], Poland [125], and Spain [126] have reported no association between Val66Met and the risk or clinical course of PD. PD is a complex neurological disease with a multifactorial aetiology, thus, a minor to moderate role of Val66Met in specific cases in collaboration with other genetic or environmental factors cannot be excluded. The association between BDNF polymorphism and PD remains an unresolved issue, and more rigorous population-based association studies are required.

\section{Conclusions and prospects}

Neurodegenerative disorders bring about major socioeconomic burden for patients and society. Therefore, it is of great interest to understand the cellular and molecular pathological basis responsible, as there are currently no effective available therapeutic strategies to reverse or halt the degenerative process. In this review article, we discuss the potential involvement of BDNF polymorphism in several neurodegenerative disorders, and conclude that the evidence is mixed in terms of implicating the SNP in several common diseases. To answer the question, prospective cohort studies, especially with longitudinal assessments of the progression of neurodegenerative disorders, are needed. Its role in glaucoma has not been studied in depth, and since BDNF is critical to ganglion cell survival, there is the potential that the SNP may be a factor in certain subtypes of glaucoma.

The role of gender and ethnicity with respects to the BDNF Val66Met polymorphism and neurodegenerative disorders susceptibility can be further explored as differential allelic frequencies and sex effects of the polymorphism have been reported in various studies [36, 41]. Most of the published studies compared BDNF Val homozygotes with BDNF Met allele carriers due to the infrequency of BDNF Met homozygotes in Caucasian population cohorts [32]. Gene dosage studies, with sufficient power will compare all three genotypes (Val/Val, Val/Met, and Met/Met) and may potentially reveal whether any specific phenotypic effects in neurodegenerative disease pathology are truly associated with the BDNF polymorphism. The higher Met allele frequency and occurrence of Met homozygotes in Asian population may provide an opportunity for such studies $[24,32]$. Parallel studies in BDNF knock in (Val66Met) mouse models overlaid with disease models using pharmacological or genetic approaches will help understand the role of BDNF variants in these neurodegenerative conditions and analyse the human gene-disease association studies. Animal studies will provide insights into the gene-protein and gene-phenotype correlation in a tissue specific manner.

It is also necessary to investigate how the BDNF polymorphism affects the neurons and CNS phenotypes including in the retina in normal healthy subjects and potential effects with age. BDNF polymorphism has indeed been suggested to have a role in geriatric depression [127], LOAD [1], age-related changes in reasoning skills and executive function [54, 55], goaldirected behaviour in the elderly [128], and reduced Stroop interference [129], and altered cognitive abilities in the elderly [130]. Thus, aging exacerbates susceptibility to neurological diseases and may amplify the effects of the polymorphism. It has been reported that BDNF Met allele carriers were more susceptible to $\mathrm{AD}$ in early adult life, while in contrast, Val homozygotes demonstrated susceptibility to $\mathrm{AD}$ in late life [131]. Identifying whether the Val66Met regulates long-term neurodegeneration in an age-dependent manner is therefore a crucial question to be further resolved, and could help develop potential therapeutic strategies in vulnerable groups.

In addition, the BDNF polymorphism is also associated with the physiology and morphology of several brain regions in healthy individuals. An 11\% volumetric decrease of the hippocampal region (a significant reduction that is comparable to that associated with diseased conditions such as major depression [132]) has been associated with the BDNF Met allele carriage in healthy subjects [133]. It has been reported that in healthy individuals a combination of dopamine D3 receptor (DRD3) Ser/Ser genotype and BDNF Met-containing genotypes is associated with shorter interthalamic adhesion, suggesting an effect of gene-gene interaction between the two genetic variants on brain morphology in midline and medial temporal lobe structure [134]. Moreover, an increase in cortical surface area as well as related resting-state functional connectivity between the 
anterior insular and the dorsolateral prefrontal cortices (DLPFC) with respect to the dosage of Met allele is reported in a cohort of healthy Chinese subjects [135]. These studies in healthy volunteers may specify vulnerability factors for the development of disease processes associated with the dysfunction of particular regions in the brain. Therefore, BDNF polymorphisms carriage may potentially act as prognostic or diagnostic markers and may assist with the development of strategies for patient stratification, early diagnosis, and early evaluation of therapeutic efficiency of new medications.

\section{Acknowledgements}

We acknowledge funding support from National Health and Medical Research Council Australia, Macquarie University, Hillcrest Foundation, and Ophthalmic Research Institute of Australia.

\section{References}

[1] Egan MF, Kojima M, Callicott JH, Goldberg TE, Kolachana BS, Bertolino A, et al. (2003). The BDNF val66met polymorphism affects activity-dependent secretion of BDNF and human memory and hippocampal function. Cell, 112: 257-269

[2] Notaras M, Hill R, van den Buuse M (2015). The BDNF gene Val66Met polymorphism as a modifier of psychiatric disorder susceptibility: progress and controversy. Mol Psychiatry, 20: 916-930

[3] Maisonpierre PC, Belluscio L, Squinto S, Ip NY, Furth ME, Lindsay RM, et al. (1990). Neurotrophin-3: a neurotrophic factor related to NGF and BDNF. Science, 247: 1446-1451

[4] Maisonpierre PC, Le Beau MM, Espinosa R, 3rd, Ip NY, Belluscio L, de la Monte SM, et al. (1991). Human and rat brain-derived neurotrophic factor and neurotrophin-3: gene structures, distributions, and chromosomal localizations. Genomics, 10: 558-568

[5] Allen SJ, Watson JJ, Shoemark DK, Barua NU, Patel NK (2013). GDNF, NGF and BDNF as therapeutic options for neurodegeneration. Pharmacol Ther, 138: $155-175$

[6] Mowla SJ, Farhadi HF, Pareek S, Atwal JK, Morris SJ, Seidah NG, et al. (2001). Biosynthesis and posttranslational processing of the precursor to brainderived neurotrophic factor. J Biol Chem, 276: 1266012666

[7] Hock C, Heese K, Hulette C, Rosenberg C, Otten U (2000). Region-specific neurotrophin imbalances in Alzheimer disease: decreased levels of brain-derived neurotrophic factor and increased levels of nerve growth factor in hippocampus and cortical areas. Arch Neurol, 57: 846-851

[8] Allen SJ, Wilcock GK, Dawbarn D (1999). Profound and selective loss of catalytic TrkB immunoreactivity in Alzheimer's disease. Biochem Biophys Res Commun, 264: 648-651

[9] Phillips HS, Hains JM, Armanini M, Laramee GR, Johnson SA, Winslow JW (1991). BDNF mRNA is decreased in the hippocampus of individuals with Alzheimer's disease. Neuron, 7: 695-702

[10] Mogi M, Togari A, Kondo T, Mizuno Y, Komure O, Kuno S, et al. (1999). Brain-derived growth factor and nerve growth factor concentrations are decreased in the substantia nigra in Parkinson's disease. Neurosci Lett, 270: 45-48

[11] Ferrer I, Goutan E, Marin C, Rey MJ, Ribalta T (2000). Brain-derived neurotrophic factor in Huntington disease. Brain Res, 866: 257-261

[12] Shimizu E, Hashimoto K, Okamura N, Koike K, Komatsu N, Kumakiri C, et al. (2003). Alterations of serum levels of brain-derived neurotrophic factor (BDNF) in depressed patients with or without antidepressants. Biol Psychiatry, 54: 70-75

[13] Bliss TV, Collingridge GL (1993). A synaptic model of memory: long-term potentiation in the hippocampus. Nature, 361: 31-39

[14] Figurov A, Pozzo-Miller LD, Olafsson P, Wang T, Lu B (1996). Regulation of synaptic responses to highfrequency stimulation and LTP by neurotrophins in the hippocampus. Nature, 381: 706-709

[15] Korte M, Carroll P, Wolf E, Brem G, Thoenen H, Bonhoeffer $T$ (1995). Hippocampal long-term potentiation is impaired in mice lacking brain-derived neurotrophic factor. Proc Natl Acad Sci U S A, 92: 8856-8860

[16] Liepinsh E, Ilag LL, Otting G, Ibanez CF (1997). NMR structure of the death domain of the p75 neurotrophin receptor. EMBO J, 16: 4999-5005

[17] Bartkowska K, Turlejski K, Djavadian RL (2010). Neurotrophins and their receptors in early development of the mammalian nervous system. Acta Neurobiol Exp (Wars), 70: 454-467

[18] Knusel B, Beck KD, Winslow JW, Rosenthal A, Burton LE, Widmer HR, et al. (1992). Brain-derived neurotrophic factor administration protects basal forebrain cholinergic but not nigral dopaminergic neurons from degenerative changes after axotomy in the adult rat brain. J Neurosci, 12: 4391-4402

[19] Chen H, Weber AJ (2001). BDNF enhances retinal ganglion cell survival in cats with optic nerve damage. Invest Ophthalmol Vis Sci, 42: 966-974

[20] Scharfman HE, Goodman JH, Sollas AL, Croll SD (2002). Spontaneous limbic seizures after intrahippocampal infusion of brain-derived neurotrophic factor. Exp Neurol, 174: 201-214

[21] Pruunsild P, Kazantseva A, Aid T, Palm K, Timmusk T (2007). Dissecting the human BDNF locus: bidirectional transcription, complex splicing, and multiple promoters. Genomics, 90: 397-406

[22] Baj G, Tongiorgi E (2009). BDNF splice variants from the second promoter cluster support cell survival of differentiated neuroblastoma upon cytotoxic stress. J Cell Sci, 122: 36-43 
[23] Cerasa A, Tongiorgi E, Fera F, Gioia MC, Valentino P, Liguori M, et al. (2010). The effects of BDNF Val66Met polymorphism on brain function in controls and patients with multiple sclerosis: an imaging genetic study. Behav Brain Res, 207: 377-386

[24] Bian JT, Zhang JW, Zhang ZX, Zhao HL (2005). Association analysis of brain-derived neurotrophic factor (BDNF) gene $196 \mathrm{~A} / \mathrm{G}$ polymorphism with Alzheimer's disease (AD) in mainland Chinese. Neurosci Lett, 387: 11-16

[25] Sheikh HI, Hayden EP, Kryski KR, Smith HJ, Singh SM (2010). Genotyping the BDNF rs6265 (val66met) polymorphism by one-step amplified refractory mutation system PCR. Psychiatr Genet, 20: 109-112

[26] Parsian A, Sinha R, Racette B, Zhao JH, Perlmutter JS (2004). Association of a variation in the promoter region of the brain-derived neurotrophic factor gene with familial Parkinson's disease. Parkinsonism Relat Disord, 10: 213-219

[27] Tsuchihashi Z, Dracopoli NC (2002). Progress in high throughput SNP genotyping methods. Pharmacogenomics J, 2: 103-110

[28] Landegren U, Nilsson M, Kwok PY (1998). Reading bits of genetic information: methods for singlenucleotide polymorphism analysis. Genome Res, 8: 769-776

[29] Kwok PY (2001). Methods for genotyping single nucleotide polymorphisms. Annu Rev Genomics Hum Genet, 2: 235-258

[30] Terrazzino S, Cargnin S, Viana M, Sances G, Tassorelli C (2017). Brain-Derived Neurotrophic Factor Val66Met Gene Polymorphism Impacts on Migraine Susceptibility: A Meta-analysis of Case-Control Studies. Front Neurol, 8: 159

[31] Bath KG, Lee FS (2006). Variant BDNF (Val66Met) impact on brain structure and function. Cogn Affect Behav Neurosci, 6: 79-85

[32] Petryshen TL, Sabeti PC, Aldinger KA, Fry B, Fan JB, Schaffner SF, et al. (2010). Population genetic study of the brain-derived neurotrophic factor (BDNF) gene. Mol Psychiatry, 15: 810-815

[33] Pivac N, Kim B, Nedic G, Joo YH, Kozaric-Kovacic D, Hong JP, et al. (2009). Ethnic differences in brainderived neurotrophic factor Val66Met polymorphism in Croatian and Korean healthy participants. Croat Med J, 50: $43-48$

[34] Zhang H, Ozbay F, Lappalainen J, Kranzler HR, van Dyck CH, Charney DS, et al. (2006). Brain derived neurotrophic factor (BDNF) gene variants and Alzheimer's disease, affective disorders, posttraumatic stress disorder, schizophrenia, and substance dependence. Am J Med Genet B Neuropsychiatr Genet, 141B: 387-393

[35] Ventriglia M, Bocchio Chiavetto L, Benussi L, Binetti G, Zanetti O, Riva MA, et al. (2002). Association between the BDNF $196 \mathrm{~A} / \mathrm{G}$ polymorphism and sporadic Alzheimer's disease. Mol Psychiatry, 7: 136137

[36] Shimizu E, Hashimoto K, Iyo M (2004). Ethnic difference of the BDNF 196G/A (val66met) polymorphism frequencies: the possibility to explain ethnic mental traits. Am J Med Genet B Neuropsychiatr Genet, 126B: 122-123

[37] Olin D, MacMurray J, Comings DE (2005). Risk of late-onset Alzheimer's disease associated with BDNF C270T polymorphism. Neurosci Lett, 381: 275-278

[38] Mirowska-Guzel D, Mach A, Gromadzka G, Czlonkowski A, Czlonkowska A (2008). BDNF A196G and C270T gene polymorphisms and susceptibility to multiple sclerosis in the Polish population. Gender differences. J Neuroimmunol, 193: 170-172

[39] Weinstock-Guttman B, Benedict RH, Tamano-Blanco M, Ramasamy DP, Stosic M, Polito J, et al. (2011). The rs2030324 SNP of brain-derived neurotrophic factor (BDNF) is associated with visual cognitive processing in multiple sclerosis. Pathophysiology, 18: 43-52

[40] Bodner SM, Berrettini W, van Deerlin V, Bennett DA, Wilson RS, Trojanowski JQ, et al. (2005). Genetic variation in the brain derived neurotrophic factor gene in Alzheimer's disease. Am J Med Genet B Neuropsychiatr Genet, 134B: 1-5

[41] Fukumoto N, Fujii T, Combarros O, Kamboh MI, Tsai SJ, Matsushita S, et al. (2010). Sexually dimorphic effect of the Val66Met polymorphism of BDNF on susceptibility to Alzheimer's disease: New data and meta-analysis. Am J Med Genet B Neuropsychiatr Genet, 153B: 235-242

[42] Vepsalainen S, Castren E, Helisalmi S, Iivonen S, Mannermaa A, Lehtovirta M, et al. (2005). Genetic analysis of BDNF and TrkB gene polymorphisms in Alzheimer's disease. J Neurol, 252: 423-428

[43] Matsushita S, Arai H, Matsui T, Yuzuriha T, Urakami K, Masaki T, et al. (2005). Brain-derived neurotrophic factor gene polymorphisms and Alzheimer's disease. J Neural Transm (Vienna), 112: 703-711

[44] Mero IL, Smestad C, Lie BA, Lorentzen AR, Sandvik L, Landro NI, et al. (2012). Polymorphisms of the BDNF gene show neither association with multiple sclerosis susceptibility nor clinical course. J Neuroimmunol, 244: 107-110

[45] Reichardt LF (2006). Neurotrophin-regulated signalling pathways. Philos Trans R Soc Lond B Biol Sci, 361: 1545-1564

[46] Chen ZY, Jing D, Bath KG, Ieraci A, Khan T, Siao CJ, et al. (2006). Genetic variant BDNF (Val66Met) polymorphism alters anxiety-related behavior. Science, 314: 140-143

[47] Lang UE, Hellweg R, Sander T, Gallinat J (2009). The Met allele of the BDNF Val66Met polymorphism is associated with increased BDNF serum concentrations. Mol Psychiatry, 14: 120-122

[48] Minelli A, Zanardini R, Bonvicini C, Sartori R, Pedrini L, Gennarelli M, et al. (2011). BDNF serum levels, but not BDNF Val66Met genotype, are correlated with personality traits in healthy subjects. Eur Arch Psychiatry Clin Neurosci, 261: 323-329

[49] Ozan E, Okur H, Eker C, Eker OD, Gonul AS, Akarsu $\mathrm{N}$ (2010). The effect of depression, BDNF gene val66met polymorphism and gender on serum BDNF levels. Brain Res Bull, 81: 61-65 
[50] Zhou Z, Lu T, Xu G, Yue X, Zhu W, Ma M, et al. (2011). Decreased serum brain-derived neurotrophic factor (BDNF) is associated with post-stroke depression but not with BDNF gene Val66Met polymorphism. Clin Chem Lab Med, 49: 185-189

[51] Yoshimura R, Kishi T, Suzuki A, Umene-Nakano W, Ikenouchi-Sugita A, Hori H, et al. (2011). The brainderived neurotrophic factor (BDNF) polymorphism Val66Met is associated with neither serum BDNF level nor response to selective serotonin reuptake inhibitors in depressed Japanese patients. Prog Neuropsychopharmacol Biol Psychiatry, 35: 10221025

[52] Bus BA, Arias-Vasquez A, Franke B, Prickaerts J, de Graaf J, Voshaar RC (2012). Increase in serum brainderived neurotrophic factor in met allele carriers of the BDNF Val66Met polymorphism is specific to males. Neuropsychobiology, 65: 183-187

[53] Pezawas L, Verchinski BA, Mattay VS, Callicott JH, Kolachana BS, Straub RE, et al. (2004). The brainderived neurotrophic factor val66met polymorphism and variation in human cortical morphology. J Neurosci, 24: 10099-10102

[54] Erickson KI, Kim JS, Suever BL, Voss MW, Francis BM, Kramer AF (2008). Genetic contributions to agerelated decline in executive function: a 10-year longitudinal study of COMT and BDNF polymorphisms. Front Hum Neurosci, 2: 11

[55] Harris SE, Fox H, Wright AF, Hayward C, Starr JM, Whalley LJ, et al. (2006). The brain-derived neurotrophic factor Val66Met polymorphism is associated with age-related change in reasoning skills. Mol Psychiatry, 11: 505-513

[56] Hashimoto T, Fukui K, Takeuchi H, Yokota S, Kikuchi Y, Tomita H, et al. (2016). Effects of the BDNF Val66Met Polymorphism on Gray Matter Volume in Typically Developing Children and Adolescents. Cereb Cortex, 26: 1795-1803

[57] Quigley HA (1993). Open-angle glaucoma. N Engl J Med, 328: 1097-1106

[58] Harwerth RS, Wheat JL, Fredette MJ, Anderson DR (2010). Linking structure and function in glaucoma. Prog Retin Eye Res, 29: 249-271

[59] Quigley HA, Broman AT (2006). The number of people with glaucoma worldwide in 2010 and 2020. Br J Ophthalmol, 90: 262-267

[60] Stone EM, Fingert JH, Alward WL, Nguyen TD, Polansky JR, Sunden SL, et al. (1997). Identification of a gene that causes primary open angle glaucoma. Science, 275: 668-670

[61] Rezaie T, Child A, Hitchings R, Brice G, Miller L, Coca-Prados M, et al. (2002). Adult-onset primary open-angle glaucoma caused by mutations in optineurin. Science, 295: 1077-1079

[62] Ramdas WD, van Koolwijk LM, Lemij HG, Pasutto F, Cree AJ, Thorleifsson G, et al. (2011). Common genetic variants associated with open-angle glaucoma. Hum Mol Genet, 20: 2464-2471

[63] Vithana EN, Khor CC, Qiao C, Nongpiur ME, George R, Chen LJ, et al. (2012). Genome-wide association analyses identify three new susceptibility loci for primary angle closure glaucoma. Nat Genet, 44: 11421146

[64] Perez MT, Caminos E (1995). Expression of brainderived neurotrophic factor and of its functional receptor in neonatal and adult rat retina. Neurosci Lett, 183: 96-99

[65] Cellerino A, Kohler K (1997). Brain-derived neurotrophic factor/neurotrophin-4 receptor $\operatorname{TrkB}$ is localized on ganglion cells and dopaminergic amacrine cells in the vertebrate retina. J Comp Neurol, 386: 149160

[66] Pease ME, McKinnon SJ, Quigley HA, KerriganBaumrind LA, Zack DJ (2000). Obstructed axonal transport of BDNF and its receptor TrkB in experimental glaucoma. Invest Ophthalmol Vis Sci, 41: 764-774

[67] Mansour-Robaey S, Clarke DB, Wang YC, Bray GM, Aguayo AJ (1994). Effects of ocular injury and administration of brain-derived neurotrophic factor on survival and regrowth of axotomized retinal ganglion cells. Proc Natl Acad Sci U S A, 91: 1632-1636

[68] Ko ML, Hu DN, Ritch R, Sharma SC, Chen CF (2001). Patterns of retinal ganglion cell survival after brainderived neurotrophic factor administration in hypertensive eyes of rats. Neurosci Lett, 305: 139-142

[69] Gupta V, You Y, Li J, Gupta V, Golzan M, Klistorner A, et al. (2014). BDNF impairment is associated with age-related changes in the inner retina and exacerbates experimental glaucoma. Biochim Biophys Acta, 1842: 1567-1578

[70] Domenici L, Origlia N, Falsini B, Cerri E, Barloscio D, Fabiani C, et al. (2014). Rescue of retinal function by BDNF in a mouse model of glaucoma. PLoS One, 9: e115579

[71] Martin KR, Quigley HA, Zack DJ, Levkovitch-Verbin H, Kielczewski J, Valenta D, et al. (2003). Gene therapy with brain-derived neurotrophic factor as a protection: retinal ganglion cells in a rat glaucoma model. Invest Ophthalmol Vis Sci, 44: 4357-4365

[72] Nowak A, Szaflik JP, Gacek M, Przybylowska-Sygut K, Kaminska A, Szaflik J, et al. (2014). BDNF and HSP gene polymorphisms and their influence on the progression of primary open-angle glaucoma in a Polish population. Arch Med Sci, 10: 1206-1213

[73] Calabresi PA (2004). Diagnosis and management of multiple sclerosis. Am Fam Physician, 70: 1935-1944

[74] Browne P, Chandraratna D, Angood C, Tremlett H, Baker C, Taylor BV, et al. (2014). Atlas of Multiple Sclerosis 2013: A growing global problem with widespread inequity. Neurology, 83: 1022-1024

[75] Organization WH (2008). Atlas. Multiple sclerosis resources in the world 2008. Atlas Multiple Sclerosis Resources in the World, 98: 103-122

[76] International Multiple Sclerosis Genetics C, Hafler DA, Compston A, Sawcer S, Lander ES, Daly MJ, et al. (2007). Risk alleles for multiple sclerosis identified by a genomewide study. N Engl J Med, 357: 851-862

[77] Australia, New Zealand Multiple Sclerosis Genetics C (2009). Genome-wide association study identifies new 
multiple sclerosis susceptibility loci on chromosomes 12 and 20. Nat Genet, 41: 824-828

[78] Jensen CJ, Stankovich J, Van der Walt A, Bahlo M, Taylor BV, van der Mei IA, et al. (2010). Multiple sclerosis susceptibility-associated SNPs do not influence disease severity measures in a cohort of Australian MS patients. PLoS One, 5: e10003

[79] Liguori M, Fera F, Patitucci A, Manna I, Condino F, Valentino P, et al. (2009). A longitudinal observation of brain-derived neurotrophic factor mRNA levels in patients with relapsing-remitting multiple sclerosis. Brain Res, 1256: 123-128

[80] Liguori M, Fera F, Gioia MC, Valentino P, Manna I, Condino F, et al. (2007). Investigating the role of brainderived neurotrophic factor in relapsing-remitting multiple sclerosis. Genes Brain Behav, 6: 177-183

[81] Ramasamy DP, Ramanathan M, Cox JL, Antulov R, Weinstock-Guttman B, Bergsland N, et al. (2011). Effect of Met66 allele of the BDNF rs6265 SNP on regional gray matter volumes in patients with multiple sclerosis: A voxel-based morphometry study. Pathophysiology, 18: 53-60

[82] Zivadinov R, Weinstock-Guttman B, Benedict R, Tamano-Blanco M, Hussein S, Abdelrahman N, et al. (2007). Preservation of gray matter volume in multiple sclerosis patients with the Met allele of the rs6265 (Val66Met) SNP of brain-derived neurotrophic factor. Hum Mol Genet, 16: 2659-2668

[83] Dinacci D, Tessitore A, Russo A, De Bonis ML, Lavorgna L, Picconi O, et al. (2011). BDNF Val66Met polymorphism and brain volumes in multiple sclerosis. Neurol Sci, 32: 117-123

[84] Fera F, Passamonti L, Cerasa A, Gioia MC, Liguori M, Manna I, et al. (2013). The BDNF Val66Met polymorphism has opposite effects on memory circuits of multiple sclerosis patients and controls. PLoS One, 8: e61063

[85] Santoro M, Nociti V, De Fino C, Caprara A, Giordano R, Palomba N, et al. (2016). Depression in multiple sclerosis: effect of brain derived neurotrophic factor Val66Met polymorphism and disease perception. Eur J Neurol, 23: 630-640

[86] Lindquist S, Schott BH, Ban M, Compston DA, Sawcer S, Sailer M (2005). The BDNF-Val66Met polymorphism: implications for susceptibility to multiple sclerosis and severity of disease. J Neuroimmunol, 167: 183-185

[87] Blanco Y, Gomez-Choco M, Arostegui JL, Casanova B, Martinez-Rodriguez JE, Bosca I, et al. (2006). No association of the Val66Met polymorphism of brainderived neurotrophic factor (BDNF) to multiple sclerosis. Neurosci Lett, 396: 217-219

[88] Sadovnick AD, Ebers GC (1993). Epidemiology of multiple sclerosis: a critical overview. Can J Neurol Sci, 20: $17-29$

[89] Rosati G (2001). The prevalence of multiple sclerosis in the world: an update. Neurol Sci, 22: 117-139

[90] Kira J (2003). Multiple sclerosis in the Japanese population. Lancet Neurol, 2: 117-127
[91] Cabre P, Signate A, Olindo S, Merle H, CaparrosLefebvre D, Bera O, et al. (2005). Role of return migration in the emergence of multiple sclerosis in the French West Indies. Brain, 128: 2899-2910

[92] Cossburn M, Tackley G, Baker K, Ingram G, Burtonwood M, Malik G, et al. (2012). The prevalence of neuromyelitis optica in South East Wales. Eur J Neurol, 19: 655-659

[93] Mattson MP (2004). Pathways towards and away from Alzheimer's disease. Nature, 430: 631-639

[94] Brookmeyer R, Johnson E, Ziegler-Graham K, Arrighi HM (2007). Forecasting the global burden of Alzheimer's disease. Alzheimers Dement, 3: 186-191

[95] Herrmann N, Chau SA, Kircanski I, Lanctot KL (2011). Current and emerging drug treatment options for Alzheimer's disease: a systematic review. Drugs, 71: 2031-2065

[96] Goate A, Chartier-Harlin MC, Mullan M, Brown J, Crawford F, Fidani L, et al. (1991). Segregation of a missense mutation in the amyloid precursor protein gene with familial Alzheimer's disease. Nature, 349: 704-706

[97] Rogaev EI, Sherrington R, Rogaeva EA, Levesque G, Ikeda M, Liang Y, et al. (1995). Familial Alzheimer's disease in kindreds with missense mutations in a gene on chromosome 1 related to the Alzheimer's disease type 3 gene. Nature, 376: 775-778

[98] Levy-Lahad E, Wasco W, Poorkaj P, Romano DM, Oshima J, Pettingell WH, et al. (1995). Candidate gene for the chromosome 1 familial Alzheimer's disease locus. Science, 269: 973-977

[99] Selkoe DJ (2001). Alzheimer's disease: genes, proteins, and therapy. Physiol Rev, 81: 741-766

[100] Lim YY, Villemagne VL, Laws SM, Ames D, Pietrzak RH, Ellis KA, et al. (2014). Effect of BDNF Val66Met on memory decline and hippocampal atrophy in prodromal Alzheimer's disease: a preliminary study. PLoS One, 9: e86498

[101] Lim YY, Villemagne VL, Laws SM, Ames D, Pietrzak RH, Ellis KA, et al. (2013). BDNF Val66Met, Abeta amyloid, and cognitive decline in preclinical Alzheimer's disease. Neurobiol Aging, 34: 2457-2464

[102] Lim YY, Hassenstab J, Cruchaga C, Goate A, Fagan AM, Benzinger TL, et al. (2016). BDNF Val66Met moderates memory impairment, hippocampal function and tau in preclinical autosomal dominant Alzheimer's disease. Brain, 139: 2766-2777

[103] Nishimura M, Kuno S, Kaji R, Kawakami H (2005). Brain-derived neurotrophic factor gene polymorphisms in Japanese patients with sporadic Alzheimer's disease, Parkinson's disease, and multiple system atrophy. Mov Disord, 20: 1031-1033

[104] Tsai SJ, Hong CJ, Liu HC, Liu TY, Hsu LE, Lin CH (2004). Association analysis of brain-derived neurotrophic factor Val66Met polymorphisms with Alzheimer's disease and age of onset. Neuropsychobiology, 49: 10-12

[105] Combarros O, Infante J, Llorca J, Berciano J (2004). Polymorphism at codon 66 of the brain-derived neurotrophic factor gene is not associated with sporadic 
Alzheimer's disease. Dement Geriatr Cogn Disord, 18: 55-58

[106] Bagnoli S, Nacmias B, Tedde A, Guarnieri BM, Cellini E, Petruzzi C, et al. (2004). Brain-derived neurotrophic factor genetic variants are not susceptibility factors to Alzheimer's disease in Italy. Ann Neurol, 55: 447-448

[107] Lee J, Fukumoto H, Orne J, Klucken J, Raju S, Vanderburg CR, et al. (2005). Decreased levels of BDNF protein in Alzheimer temporal cortex are independent of BDNF polymorphisms. Exp Neurol, 194: 91-96

[108] Kunugi H, Ueki A, Otsuka M, Isse K, Hirasawa H, Kato $\mathrm{N}$, et al. (2001). A novel polymorphism of the brainderived neurotrophic factor (BDNF) gene associated with late-onset Alzheimer's disease. Mol Psychiatry, 6: 83-86

[109] Foltynie T, Lewis SG, Goldberg TE, Blackwell AD, Kolachana BS, Weinberger DR, et al. (2005). The BDNF Val66Met polymorphism has a gender specific influence on planning ability in Parkinson's disease. J Neurol, 252: 833-838

[110] Warner TT, Schapira AH (2003). Genetic and environmental factors in the cause of Parkinson's disease. Ann Neurol, 53 Suppl 3: S16-23; discussion S23-15

[111] Howells DW, Porritt MJ, Wong JY, Batchelor PE, Kalnins R, Hughes AJ, et al. (2000). Reduced BDNF mRNA expression in the Parkinson's disease substantia nigra. Exp Neurol, 166: 127-135

[112] Scalzo P, Kummer A, Bretas TL, Cardoso F, Teixeira AL (2010). Serum levels of brain-derived neurotrophic factor correlate with motor impairment in Parkinson's disease. J Neurol, 257: 540-545

[113] Momose Y, Murata M, Kobayashi K, Tachikawa M, Nakabayashi Y, Kanazawa I, et al. (2002). Association studies of multiple candidate genes for Parkinson's disease using single nucleotide polymorphisms. Annals of neurology, 51: 133-136

[114] Karamohamed S, Latourelle JC, Racette BA, Perlmutter JS, Wooten GF, Lew M, et al. (2005). BDNF genetic variants are associated with onset age of familial Parkinson disease: GenePD Study. Neurology, 65: 1823-1825

[115] Guerini FR BE, Riboldazzi G, Zangaglia R, Pianezzola C, Bono G, et al. (2009). BDNF Val66Met polymorphism is associated with cognitive impairment in Italian patients with Parkinson's disease. European Journal of Neurology, 16: 1240-1245

[116] Altmann V, Schumacher-Schuh AF, Rieck M, Callegari-Jacques SM, Rieder CR, Hutz MH (2016). Val66Met BDNF polymorphism is associated with Parkinson's disease cognitive impairment. Neurosci Lett, 615: 88-91

[117] Foltynie T, Cheeran B, Williams-Gray CH, Edwards MJ, Schneider SA, Weinberger D, et al. (2009). BDNF val66met influences time to onset of levodopa induced dyskinesia in Parkinson's disease. J Neurol Neurosurg Psychiatry, 80: 141-144

[118] van der Kolk NM, Speelman AD, van Nimwegen M, Kessels RP, IntHout J, Hakobjan M, et al. (2015).
BDNF polymorphism associates with decline in set shifting in Parkinson's disease. Neurobiol Aging, 36: 1605 e $1601-1606$

[119] Saarela MS, Lehtimaki T, Rinne JO, Huhtala H, Rontu $\mathrm{R}$, Hervonen A, et al. (2006). No association between the brain-derived neurotrophic factor $196 \mathrm{G}>\mathrm{A}$ or 270 $\mathrm{C}>\mathrm{T}$ polymorphisms and Alzheimer's or Parkinson's disease. Folia Neuropathol, 44: 12-16

[120] Hakansson A, Melke J, Westberg L, Shahabi HN, Buervenich S, Carmine A, et al. (2003). Lack of association between the BDNF Val66Met polymorphism and Parkinson's disease in a Swedish population. Ann Neurol, 53: 823

[121] Hong CJ, Liu HC, Liu TY, Lin CH, Cheng CY, Tsai SJ (2003). Brain-derived neurotrophic factor (BDNF) Val66Met polymorphisms in Parkinson's disease and age of onset. Neurosci Lett, 353: 75-77

[122] Chen CM, Chen IC, Chang KH, Chen YC, Lyu RK, Liu YT, et al. (2007). Nuclear receptor NR4A2 IVS6 +18 insG and brain derived neurotrophic factor (BDNF) V66M polymorphisms and risk of Taiwanese Parkinson's disease. Am J Med Genet B Neuropsychiatr Genet, 144B: 458-462

[123] Xiromerisiou G, Hadjigeorgiou GM, Eerola J, Fernandez HH, Tsimourtou V, Mandel R, et al. (2007). BDNF tagging polymorphisms and haplotype analysis in sporadic Parkinson's disease in diverse ethnic groups. Neurosci Lett, 415: 59-63

[124] Karakasis C, Kalinderi K, Katsarou Z, Fidani L, Bostantjopoulou S (2011). Association of brain-derived neurotrophic factor (BDNF) Val66Met polymorphism with Parkinson's disease in a Greek population. J Clin Neurosci, 18: 1744-1745

[125] Bialecka M, Kurzawski M, Roszmann A, Robowski P, Sitek EJ, Honczarenko K, et al. (2014). BDNF G196A (Val66Met) polymorphism associated with cognitive impairment in Parkinson's disease. Neurosci Lett, 561: 86-90

[126] Gao L, Diaz-Corrales FJ, Carrillo F, Diaz-Martin J, Caceres-Redondo MT, Carballo M, et al. (2010). Brainderived neurotrophic factor G196A polymorphism and clinical features in Parkinson's disease. Acta Neurol Scand, 122: 41-45

[127] Hwang JP, Tsai SJ, Hong CJ, Yang CH, Lirng JF, Yang YM (2006). The Val66Met polymorphism of the brainderived neurotrophic-factor gene is associated with geriatric depression. Neurobiol Aging, 27: 1834-1837

[128] Getzmann S, Gajewski PD, Hengstler JG, Falkenstein M, Beste C (2013). BDNF Val66Met polymorphism and goal-directed behavior in healthy elderly - evidence from auditory distraction. Neuroimage, 64: 290-298

[129] Gajewski PD, Hengstler JG, Golka K, Falkenstein M, Beste C (2012). The Met-genotype of the BDNF Val66Met polymorphism is associated with reduced Stroop interference in elderly. Neuropsychologia, 50: 3554-3563

[130] Miyajima F, Ollier W, Mayes A, Jackson A, Thacker N, Rabbitt P, et al. (2008). Brain-derived neurotrophic factor polymorphism Val66Met influences cognitive abilities in the elderly. Genes Brain Behav, 7: 411-417 
[131] Voineskos AN, Lerch JP, Felsky D, Shaikh S, Rajji TK, Miranda D, et al. (2011). The brain-derived neurotrophic factor Val66Met polymorphism and prediction of neural risk for Alzheimer disease. Arch Gen Psychiatry, 68: 198-206

[132] Videbech P, Ravnkilde B (2004). Hippocampal volume and depression: a meta-analysis of MRI studies. Am J Psychiatry, 161: 1957-1966

[133] Bueller JA, Aftab M, Sen S, Gomez-Hassan D, Burmeister M, Zubieta JK (2006). BDNF Val66Met allele is associated with reduced hippocampal volume in healthy subjects. Biol Psychiatry, 59: 812-815
[134] Takahashi T, Suzuki M, Tsunoda M, Kawamura Y, Takahashi N, Maeno N, et al. (2008). The association of genotypic combination of the DRD3 and BDNF polymorphisms on the adhesio interthalamica and medial temporal lobe structures. Prog Neuropsychopharmacol Biol Psychiatry, 32: 12361242

[135] Wang C, Zhang Y, Liu B, Long H, Yu C, Jiang T (2014). Dosage effects of BDNF Val66Met polymorphism on cortical surface area and functional connectivity. J Neurosci, 34: 2645-2651 